\title{
Investigation of interlocking effect of crushed stone ballast during dynamic loading
}

\author{
Mykola Sysyn ${ }^{1}$, Olga Nabochenko², Vitalii Kovalchuk², Michał Przybyłowicz' ${ }^{1}$, Szabolcs Fischer $^{3}$ \\ ${ }^{1}$ Institute of Railway Systems and Public Transport, TU Dresden, Dresden, Germany, \\ e-mail: mykola.sysyn@tu-dresden.de \\ e-mail: przybylowiczmichal@gmail.com \\ ${ }^{2}$ Department of the Rolling Stock and Track, Lviv Branch of Dnipropetrovsk National University of Railway Transport, \\ Lviv, Ukraine \\ e-mail: olganabochenko@gmail.com \\ e-mail: kovalchuk.diit@gmail.com \\ ${ }^{3}$ Department of Transport Infrastructure and Water Resources Engineering, Szechenyi Istvan University, Gyor, Hungary, \\ e-mail: fischersz@sze.hu
}

\begin{tabular}{l}
\hline Article Info \\
\hline Article history: \\
Received February 18, 2021 \\
Revised April 3, 2021 \\
Accepted April 5, 2021 \\
\hline
\end{tabular}

\section{Keywords:}

Railway ballast,

Experimental measurements,

Ballast particle interlocking,

Residual stress,

Ballast compaction.

\begin{abstract}
The present paper deals with the experimental investigation of interlocking effect of crushed stone ballast material, assessing it as the relationship with the residual and dynamic stresses under the ballast layer during laboratory dynamic tests with the consideration of different boundary conditions. The laboratory experiments were executed with a scaled model of ballast under the sleeper. The measured pressure at the bottom surface of the ballast has two parts: dynamic and residual. The dynamic part depends on the external loading; the residual part remains after unloading. The measured residual stress was observed up to 3 times higher than the stress due to cyclic external loading. The relationship of the residual stress and interlocking effect to ballast particles angularity is analyzed. A simple interpretation of the distribution of residual stress is proposed, that depends on the measured cyclic stress and the elasticity of bounding walls. The study of interlocking effect of ballast could be potentially useful for many practical problems of railway track design as well as for the track maintenance issues.
\end{abstract}

Copyright (C) 2020 Regional Association for Security and crisis management and European centre for operational research. All rights reserved.

\section{Corresponding Author:}

Szabolcs Fischer,

Department of Transport Infrastructure and Water Resources Engineering, Szechenyi Istvan University.

Email: fischersz@sze.hu

\section{Introduction}

Ballasted track superstructure is the most used in railroads of the world due to its flexibility of construction, operational capacity and load-bearing capability. However, during the last hundred years the length of railroads of European and especially North American railways networks gradually shrinks under the strong competence of other transport means (Fendrich \& Fengler, 2013; Esveld, 2001). Some of the main reasons are relatively high costs of railways related to maintenance and operation hindrance. The costs result from short lifecycle of some track parts and the necessity of frequent and sometimes cost-expensive inspections. The operation hindrance costs are directly related to the time of traffic interruption and operational loading of railway lines. The costs could be as high as the maintenance costs, and even higher for the lines with intensive traffic (Veit, 2013). Long-term deterioration of railway track geometry due to inhomogeneous settlements of ballast 
layer demands more frequent corrective maintenance (i.e. geometrical correction). There were many attempts (Lichtberger, 2005) in the last decades to develop the competitive ballastless superstructure, which avoids the high maintenance costs due to ballast layer. The ballastless structures are able to reduce the maintenance costs more than twice (Esveld, 2001). Despite all the attempts, the field of ballastless superstructure application is limited to high-speed lines with very intensive operational loading, mainly in Asian countries. Most of the European high-speed railways, like SNCF, prefer the application of the ballasted tracks (Gerber \& Fengler, 2009).

The frequent corrective maintenance work in track geometry relates to the mechanical properties of railway ballast. Railway ballast is unbounded grained material of crushed rock (i.e. non-cohesive) that poorly perceives the vibrational stress from dynamic loading generated by trains. The ways for reduction of track geometry deterioration due to inhomogeneous settlements of ballast layer during its maintenance and construction are summarized in Figure 1.

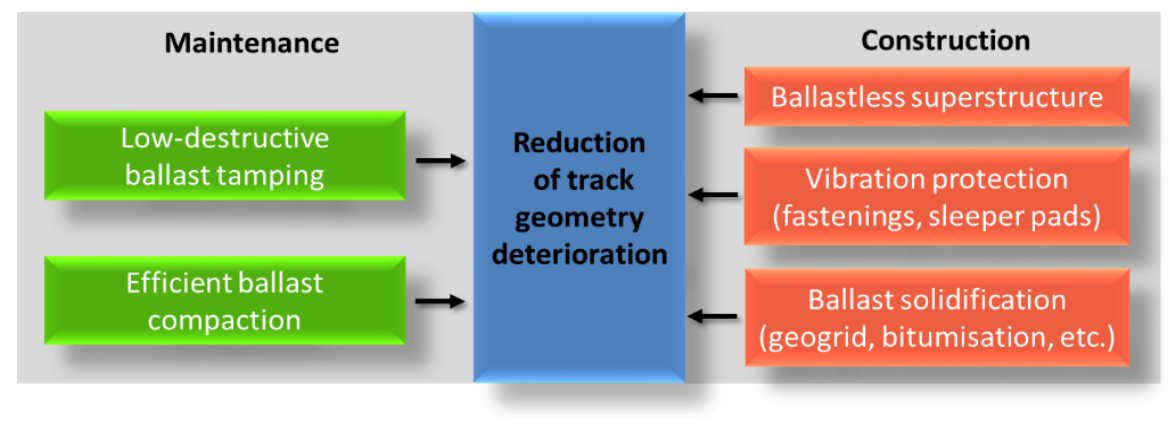

Figure 1. Maintenance and Construction Factors Influencing Track Geometry

Many recent studies have dealt with the problem of ballast layer protection from dynamic loading with elastic fastenings or under sleeper pads (Plášek \& Hruzíková, 2017; Berghold, 2016). Other studies propose some improvements of trackbed properties due to application of geogrids (Fischer \& Horvát, 2011; Fischer, 2012; Lang, Yang \& Yan, 2019), bitumisation or polyurethane foam cementing (Cai et al., 2019). The goal of the improvements is the compensation of the absent cohesive properties of ballast material with its solidification. Such ballast stabilization methods have still not found wide application due to their high cost and possible hindrances to ballast maintenance work.

A lot of recent studies are devoted to the research of railway ballast and its long-term behavior. Prediction of railway ballast lifecycle depending on its mechanical properties is considered in (Ramūnas et al., 2017; Fischer 2017; Juhász \& Fischer, 2019). The estimation of compaction quality influence of ballast backfill on carrying capacity of steel plate engineering structures is shown in (Beben, 2017; Kovalchuk et al., 2018). The study of ballast compaction during its initial stabilization phase with dynamic acceleration measurements is presented in (Sysyn et al., 2019; Nabochenko et al., 2019; Liu et al., 2018). Phenomenological modelling of inhomogeneous settlements and track geometry degradation based on the experimental measurements is proposed in (Gerber \& Fengler, 2010; Sysyn, et al., 2018). The influence of ballast abrasion on its strength properties is studied in (Kolos et al., 2017). Experimental measurement of ballast pressure between the sleeper and ballast, and under the trackbed is presented in (Liu et al., 2017; Watts, Rose \& Russell, 2018). Monitoring and prediction of quality development of ordinary ballasted track and that of transition zones is presented in (Izvolt, Harusinec \& Smalo, 2018, Izvolt, Sestakova \& Smalo, 2016). Discrete element modelling of ballast layer taking into account vibration characteristic of ballast particles and ballast breakage is presented in (Wang \& Martin, 2018; Wang et al., 2017; Wang et al., 2016; Suhr et al., 2018). The influence of railway superstructure parameters on the dynamic loadings and track geometry quality is studied in (Ižvolt et al., 2014; Izvolt \& Kardos, 2011).

The expensive ballast maintenance work, like tamping, cleaning, stabilization etc. results from the construction specialties of ballast layer. It is the only superstructure part, which properties are formed in-situ, different to other track industrially made components. Moreover, the tamping procedure itself destroys ballast particles that after repeating work, demands cost expensive cleaning with new material adding. The ability of the ballast layer to resist the long-term deformation is related to ballast material strength that depends on many parameters, like particle angularity and roughness, particle size distribution, geometrical configuration of the trackbed and ballast compaction (Fischer, 2012). The strength behavior of the crushed rock is described by the soil mechanics in a very simple analogy on the basis of the direct shear test (Figure 2), where the crushed rock on a horizontally displaceable test facility is subjected to a horizontal force $\mathrm{H}$ or shear stress; $\mathrm{A}$ is the loaded area. The shear strength $\tau_{f}$ considered to be reached, if a horizontal movement of the experimental device 
begins. In contrast to the solids, the strength is not a constant value, but changes depending on the vertical force $\mathrm{V}$ or the normal stress $\sigma$, which acts on the test device. Two material parameters appear which are called cohesion $\mathrm{c}$ and friction angle $\varphi$ :

$\tau_{f}=c+\sigma \cdot \tan \varphi$

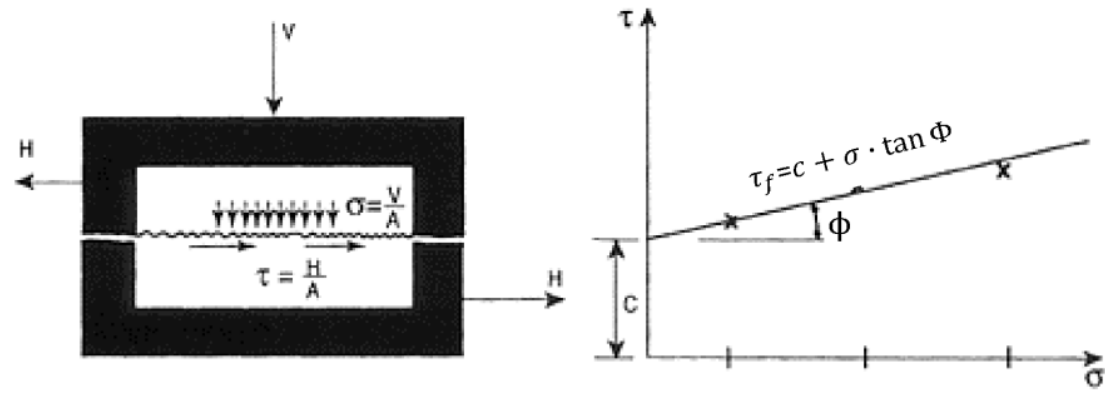

Figure 2. Direct Shear Test (Göbel 2013)

Generally, it is considered that cohesion is a measure of the adhesive power between the grains. Gravel or dry sand are typically considered as the crushed rocks without cohesion. However, many authors interpret the direct shear tests or triaxial tests results of railway ballast materials with some value of cohesion. In the study (Klotzinger, 2008) the cohesion $c$ is called toothed-surface resistance that varies in range from $42 \mathrm{kPa}$ for round gravel up to $92 \mathrm{kPa}$ for the new crushed rock. The experimental study (Kolos et al., 2017) demonstrates the changes of the railway ballast strength properties during abrasive wear. According to the study the cohesion $c$ varies in range from $56 \mathrm{kPa}$ for low abrasion degree up to $6 \mathrm{kPa}$ for the high one. The cohesion property is explained with particle angularity together with its own gravitational loading of the ballast layer. Evidentially the property, except of internal friction, plays an important role in ballast resistance to the long-term deformations. The granular material properties in another more advanced interpretation with hypo-plasticity constitutive material law is presented in (Gudehus, 2003; Herle, 1997; Meißner, 2014; Fellin, 2002), where seven material parameters are presented additionally to the critical friction angle. The accumulation of shear deformations under the cyclical loading is known as ratcheting or 'sawtooth' effect that again is related to particles angularity. However, such advanced interpretation would be difficult for applying in practical transportation and civil engineering problems.

In a $\mathrm{PhD}$ dissertation (Fischer, 2012) and in a research paper (Fischer, 2015) the interlocking effect was determined as inner shear resistance of granular materials: crushed stone railway ballast, as well as granular supplementary (protection) layers. A special multi-level shear box was constructed that contains 10 pieces of $10 \mathrm{~cm}$ height steel frames with inner dimension of $1.0 \times 1.0 \mathrm{~m}$ area (Figure 3 ).

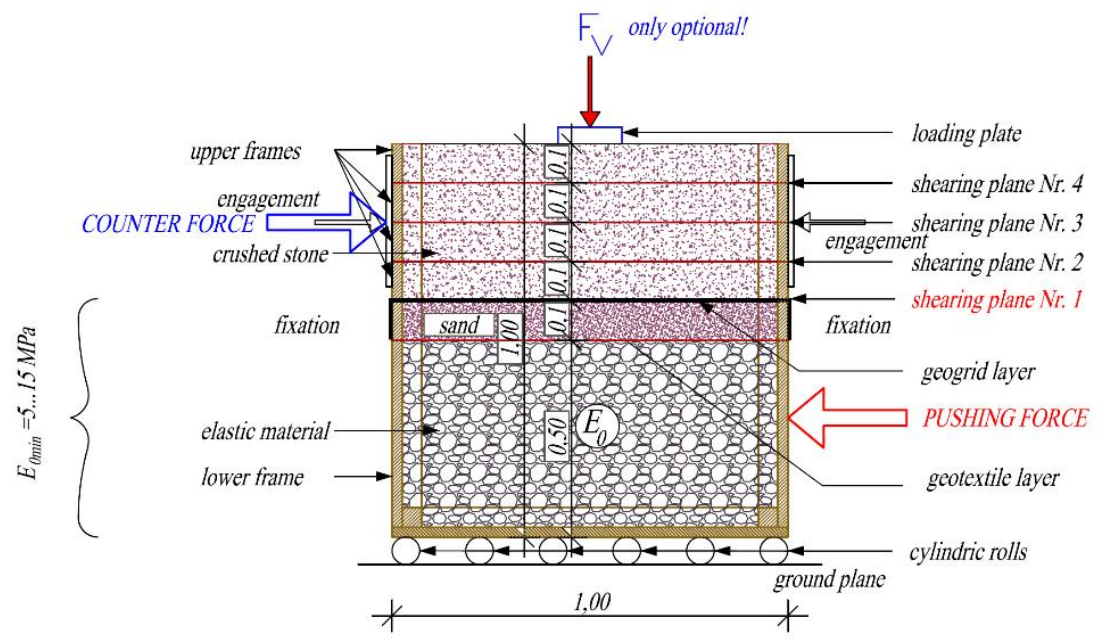

Figure 3. Measuring concept of multi-lever shear box (Fischer, 2012)

The frames can be fixed together with 4-4 pieces of vertical axis screws; or for measurement they can be removed from only that frame-frame connection where the inner shear resistance should be measured with 
horizontal direction shearing. The box is similar to a direct shear test device (see Figure 2), but it ensures measurements on more horizontal planes. The box is usually filled with $50 \mathrm{~cm}$ XPS sheets at the bottom side that simulate a soft subgrade (naturally the thickness of this layer can be modified; thinner layer provides harder, thicker layer ensures softer subgrade), a single layer of geotextile with min. $150 \mathrm{~g} / \mathrm{m} 2 \mathrm{weight}$, a sand layer with $10 \mathrm{~cm}$ thickness, above them usually $4 \times 10 \mathrm{~cm}=40 \mathrm{~cm}$ crushed stone or other granular material. Between the sand layer and the upper granular medium, geosynthetic layer is able to be incorporated. The inner shear force of the material can be measured from the upper frame to the bottom frames until the lowest one (i.e. the top of the sand layer). A test series usually contains 4 measurements related to the upper 4 planes: fixing the frames together with screws, only the at the shearing plane there isn't any screws; shearing on the upper plane (between the upper two frames) during the horizontal force (both the active and counter forces) and displacement parameters (relative displacement between the frames) are recorded; pushing back the frame the original position; fixing the upper frames together with screws, loosen the screws at the next shearing plane; shearing on the second plane, etc. With this method the inner shear force is able to be determined as a function of the vertical distance measured from the down (lower) plane. The granular material can be compacted or not, there can be geogrid reinforcement, or not. Fischer (2012) and Fischer (2015) certified that this methodology works, he proved the accurate reinforcement effect of the compaction and the geosynthetic inclusions, as well as the modification factor of combined geogrid-geotextile layer on the inner shear resistance of the granular media. The highest values are usually at the lowest plane or the plane above the lowest one. It depends on whether there is geosynthetic reinforcement layer or not, as well as the density (it was compacted or not) of the granular media. The measured inner shear resistance is actually very familiar with the interlocking effect inside the sample.

The present paper is focused on the experimental study of another measurement possibility of the ballast interlocking effect, it is considered as the residual stress in granular materials (Dingqing Li et al., 2015). The appearance of residual stress is possible if there is interaction between the ballast and elastic medium. The effect consists in the fact that the ballast layer under repeated loading tends to accumulate and remain stress even after the vertical load is removed. According to (Selig \& Waters, 1994) the magnitude of residual stress in ballast can be up to 10 times higher than the stress from the external loading, but it should be determined accurately.

\section{Interlocking mechanism and residual stress in ballast layer}

The mechanism of the ballast interlocking effect could be simply explained with flexible ballast box that is shown in Figure 4. During the initial loading, some ballast particles (Figure 3, left, red) can produce wedging action due to their angularity and position relative to other particles. The horizontal wedging contact forces can be very high if the external loading is passed through a low number of particles that have vertical orientation of angles. The side and bottom walls move under the loading and produce the reaction forces. After the cyclical loading more particles interlock together and to the movable walls.
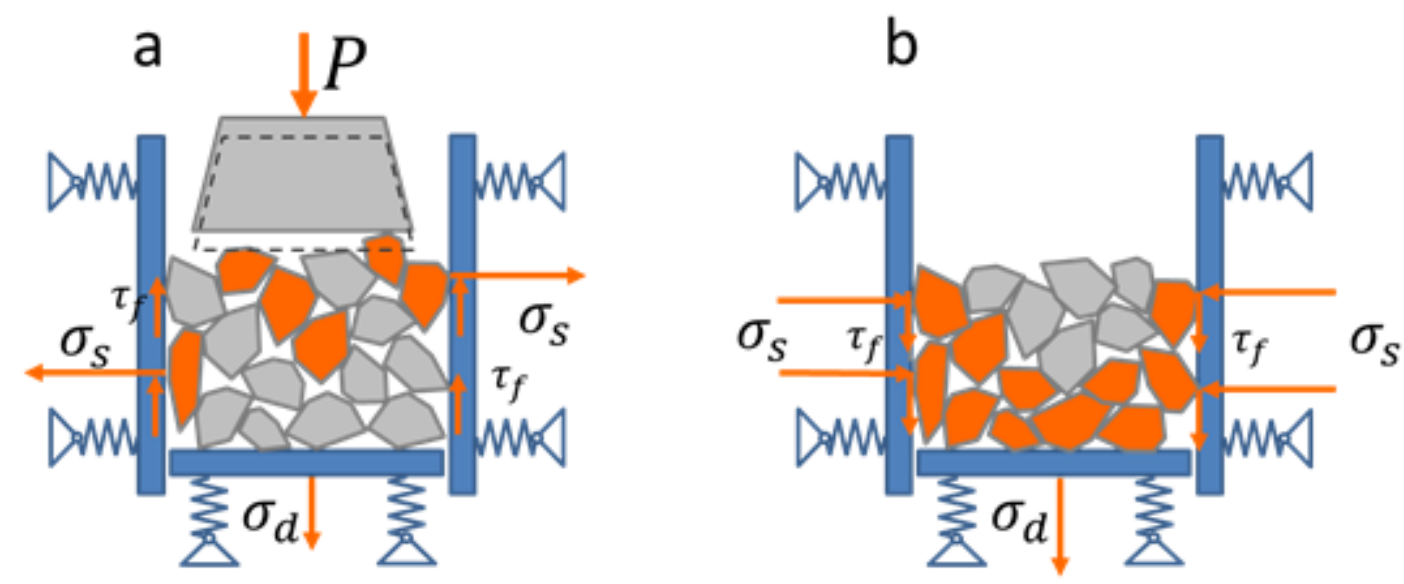

Figure 4. Explanation of the interlocking mechanism (left a: cyclic external loading, right b: interlocked ballast particles and residual pressure) 
When the load is removed (Figure 4, right), the particle is held tightly in position due to friction works between the granular media and the side walls. The horizontal reaction loading together with ballast friction to the walls produces in turn the pressure on the bottom wall. The magnitude of residual stress in ballast has some relation to the ballast particle form and angularity. It relates to the cohesion intercept on the y-axis in a MohrCoulomb stress diagram (Figure 2, right). However, different from the cohesion intercept, it depends on the history of external loading. Therefore, the relation (1) could be expanded with the corresponding part:

$\tau_{f}=c+c_{\text {inter }}\left(\max \left(\sigma_{\text {res }}\right)\right)+\sigma \cdot \tan \phi$

The part of shear resistance $c_{\text {inter }}\left(\max \left(\sigma_{\text {res }}\right)\right)$ can have the significant weight in the overall ballast strength. Hence, the research how the part could be controlled and what the influence is on the long-term behavior of ballast, could be promising for many practical applications.

The present paper deals with the experimental investigation of the ballast residual stress under the sleeper during dynamic vibrational loading and different boundary conditions. The main goal of the research is to execute experimental measurement to be able to determine the ballast stress that relates to interlocking effect and interpretation of stress distribution along the sleeper under the ballast layer and relating to the simulated tamping cycle.

\section{Scaled laboratory tests and measurements}

The laboratory setup for the ballast research is presented with the box of the size $1.0 \times 0.17 \times 0.33 \mathrm{~m}$ that is filled with crushed stone (Figure 5). The side walls of the box are thick-walled glass plates to monitor the flow of ballast particles and carry out the photogrammetric measurements. The ballast material is crushed stone of granite with fraction $8-16 \mathrm{~mm}$, which fills the entire volume of the box to the depth of $0.27 \mathrm{~m}$ without consolidation and compaction. The short side walls are capable to move outside when the ballast pressure reaches friction resistance. The bottom of the box consists of $n$-shaped profiles, where signal cables and power supply to the sensors are placed. The total number of pressure sensors is 11 pieces.

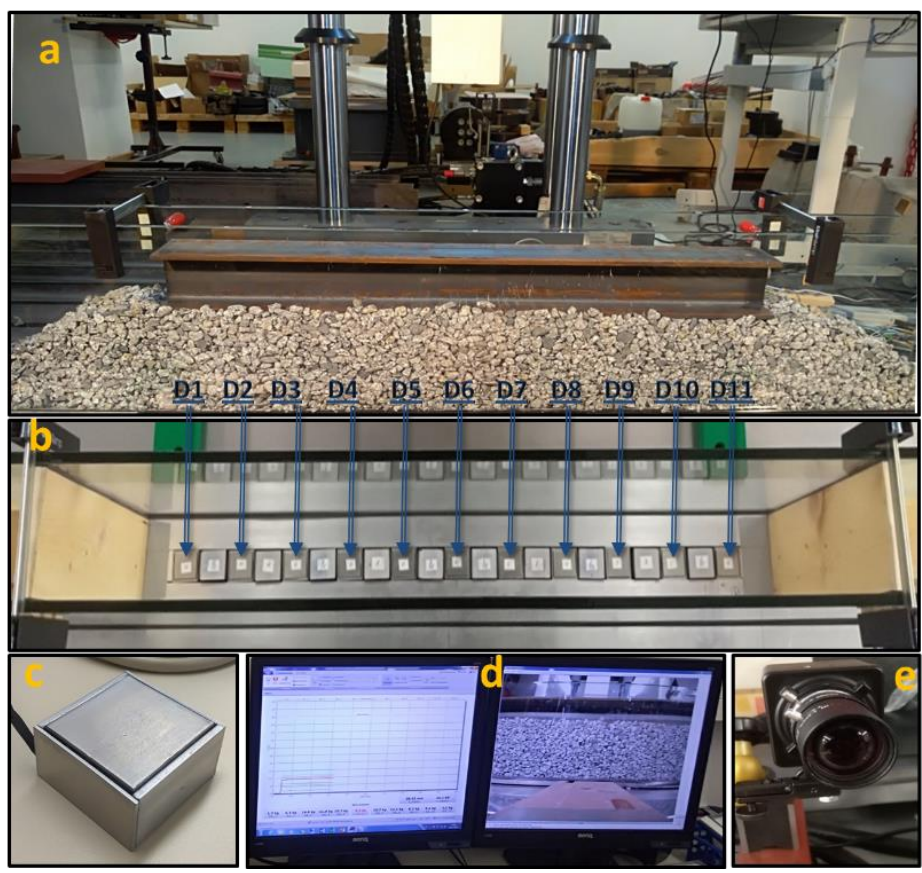

Figure 5. Experimental measurements of ballast pressure in the scale test (top a: view from the side of the ballast in the box with glass walls; middle b: position of pressure sensors under the ballast; left down c: designed load cell; down middle d: pressure and video measurements; down right e: high speed camera)

After the hydropulse device ZWICK HB 160 loads ballast, the pressure sensors send a signal to the measuring system. The photogrammetric measurements were carried out with high speed camera synchronously with pressure measurements. 
The pressure sensors are metal boxes of size $4.0 \times 4.0 \times 2.0 \mathrm{~cm}$, inside which there are two consecutively connected half-bridge load cells modules with strain gauges. The load cells are connected to each other by a full bridge circuit for measurement signal balancing. The maximum nominal load on the sensor is $50 \mathrm{~kg}$, which allows performing stress measurements up to $0.4 \mathrm{MPa}$ without the nonlinearity correction. The dimensions of the active surface of the sensor are selected regarding the need to measure the pressure of the granular ballast material. In experimental laboratory studies, the model (scaled) ballast of fraction 8-16 mm is used, which is quite sufficient for stable measurement of pressure by developed load cells.

The laboratory studies of stresses under the ballast were performed by a sequence of load cycles with ZWICK HB 160 hydropulse device. The ballast load was transmitted through a metal I-beam. The geometric dimensions of the beam are chosen so that while transferring loads from the hydropulse device, the entire perimeter of the ballast layer is covered. In each cycle of the experiment, the controlled static and dynamic load with a Zwick HB160 loading machine is applied to the stamp and simultaneously the dynamic vertical movement of a sleeper is measured. In the initial cycles, the load corresponds to the cyclic load from the rolling stock with preloading and the dynamic component. For each next cycle, the load rises. The end cycle corresponds to vibration loading with a frequency close to the natural frequency the rail track. Such a loading should cause to the fastest accumulation of irreversible deformations in the ballast layer. The program of experiments is shown in Table 1.

Table 1. Program of Dynamic Loading on the Ballast Layer

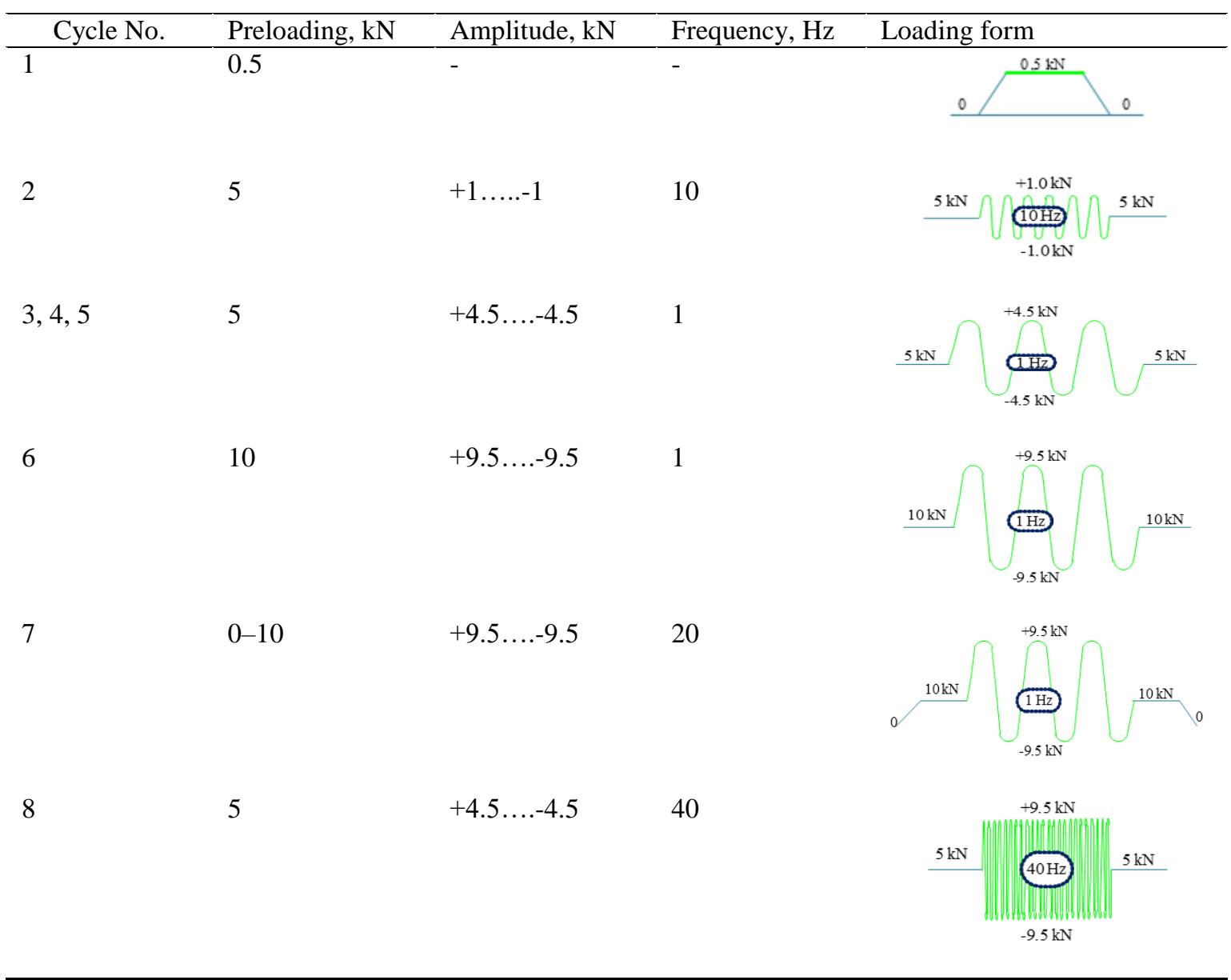

At the cycle No. 1 of the experiment, the static load of $0.5 \mathrm{kN}$ and duration of 30 seconds were applied. The residual subsidence of the ballast was not observed. During cycle No. 2, a constant load of $5 \mathrm{kN}$ and further dynamic harmonic load at the frequency of $10 \mathrm{~Hz}$ and the amplitude of $1 \mathrm{kN}$ were applied. At the loading, the ballast layer settlement under the sleeper was $0.8 \mathrm{~mm}$.

In load cycles No. 3, No. 4 and No. 5, a smooth change in the load from $0 \mathrm{kN}$ to $5 \mathrm{kN}$ and further dynamic harmonic load at the frequency of $1 \mathrm{~Hz}$ in the range from $-4.5 \mathrm{kN}$ to $+4.5 \mathrm{kN}$ were applied. The total subsidence of the ballast in experiment number 3 was $3.5 \mathrm{~mm}$ for 35 load cycles; in experiment number 4 it was $7 \mathrm{~mm}$ for 25 load cycles, and in experiment number 5 it was $6 \mathrm{~mm}$ for 35 load cycles. 
Through experimental load cycle No. 6 the static load was $10 \mathrm{kN}$ together with dynamic harmonic load at the frequency of $1 \mathrm{~Hz}$ in the range from $-9.5 \mathrm{kN}$ to $+9.5 \mathrm{kN}$ was applied. The ballast subsidence under the sleeper was $9.5 \mathrm{~mm}$ per 100 load cycles. While performing cycle No. 7, the smooth change in load from $0 \mathrm{kN}$ to $10 \mathrm{kN}$ was used with further dynamic harmonic load at the frequency of $1 \mathrm{~Hz}$ in the range from $-9.5 \mathrm{kN}$ to $+9.5 \mathrm{kN}$ was applied. The total subsidence of the ballast in experiment number 7 was $14 \mathrm{~mm}$ per 100 load cycles.

In the eighth cycle, the static load was $5 \mathrm{kN}$, and the total dynamic load on the stamp was $19 \mathrm{kN}$ at the frequency of $40 \mathrm{~Hz}$. During the experiment there was a complete unloading of the ballast. The ballast subsidence under the sleeper was $19 \mathrm{~mm}$ per 1200 cycles of harmonic load for 30 seconds. The change of the shape of the ballast layer and types of loads as well as the results of a sleeper subsidence in eight different experimental load cycles are shown in Figure 6.
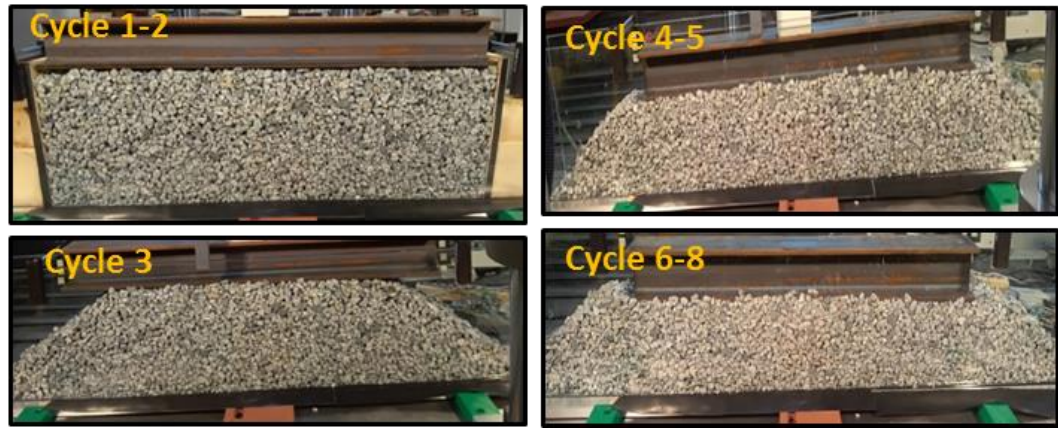

Figure 6. The form of ballast layer during loading cycles 1-8

The external loading of the sleeper in all 8 cycles and its settlements are shown in Figure 7. The most intensive settlement values were able to be measured in the last cycle under the vibration loading.
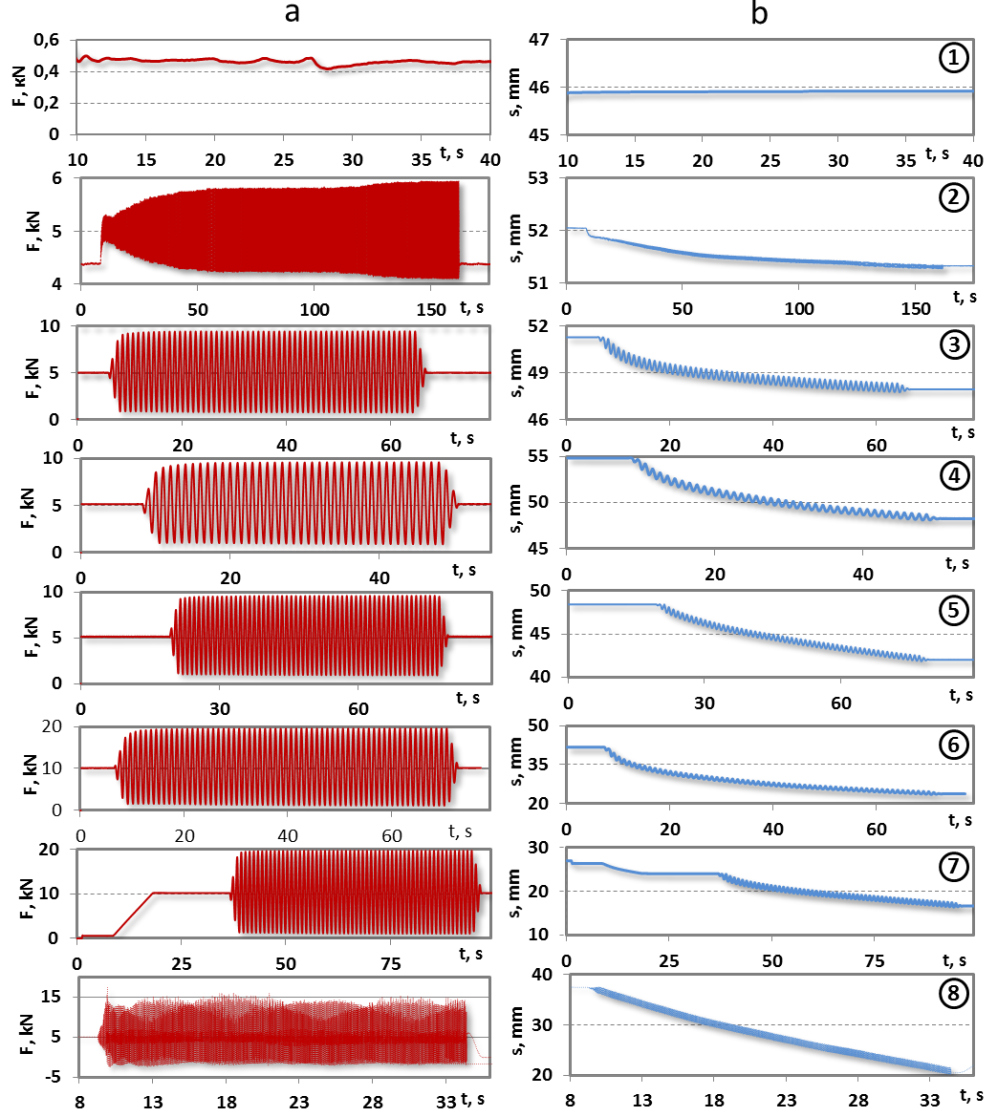

Figure 7. The loadings on the sleeper (left row a) and its settlements (right row b) for the cycles 1-8 


\section{Analysis and interpretation of pressure under the ballast layer}

The pressure under the ballast layer was measured for one calibration of loading cells before the experiment. The dynamic stress distributions that are shown in Figure 8 represent the measured stress increments without the stress values at the beginning of each cycle. Figure 9 shows the residual stresses, which are the initial measured stress for each cycle without the external loading. The magnitude and the form of the dynamic and residual stresses is quite different. The residual stresses are about 3 times higher than the dynamic ones under the central part of the sleeper. However, different to them, the residual stresses intensively fall down in points out of the central part. The dynamic stresses decrease more or less uniform from the central part to the sleeper ends especially after the 5 th cycle where all ballast layer supports the sleeper.

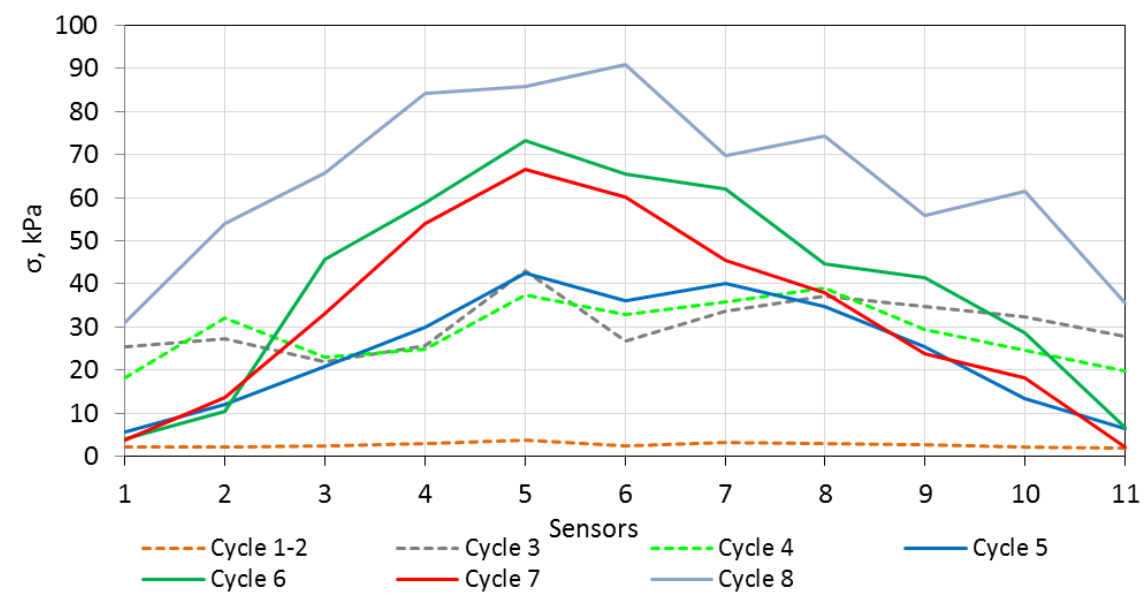

Figure 8. The dynamic stresses under the ballast layer

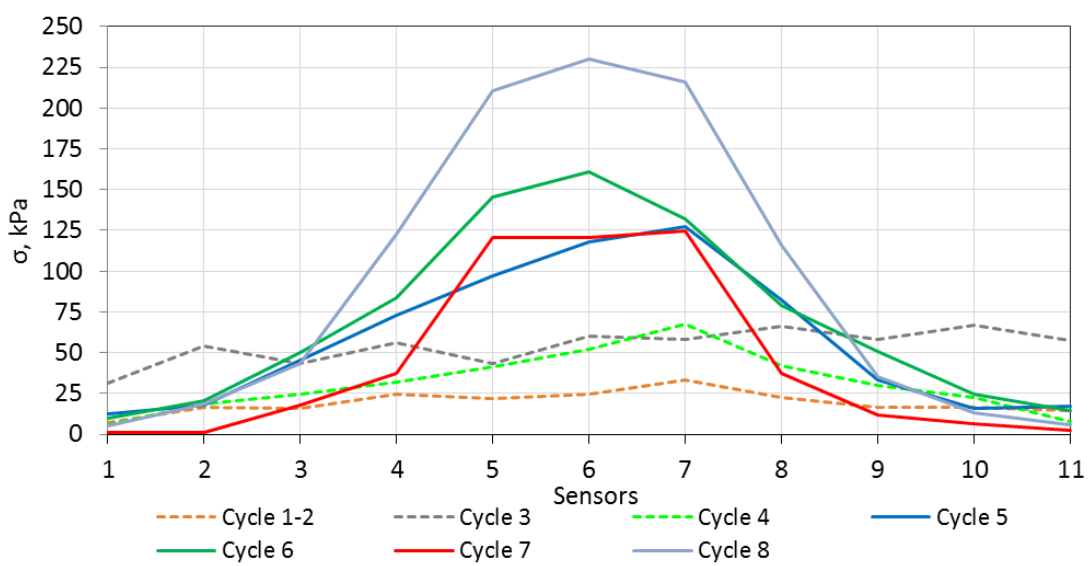

Figure 9. The residual stresses under the ballast Layer

The specialty of the dynamic and residual stress distribution under the ballast layer in the first cycles is almost homogenous distribution along the sleeper. Figure 10 demonstrates the pressure process during time of all cycle tests for two load cells: under the sleeper side and under the sleeper center. During the first 3 cycles the pressure both for side and central sensors grow. Thereby, the pressure in the central sensor for the cycles No. 1 and No.2 is somewhat higher than in the side one. Through the cycle No. 3, after the action of $10 \mathrm{kN}$ cyclic loading on the sleeper, the average residual stresses become almost the same. After the fourth cycle, the both ends of ballast layer are done free, and therefore the ballast pressure is concentrated under the middle part of the sleeper. The residual and dynamic pressure in load cell under the sleeper side decreases and stays not more than $20 \mathrm{kPa}$ until the cycle 8 despite of the double external loading increment on the sleeper. 


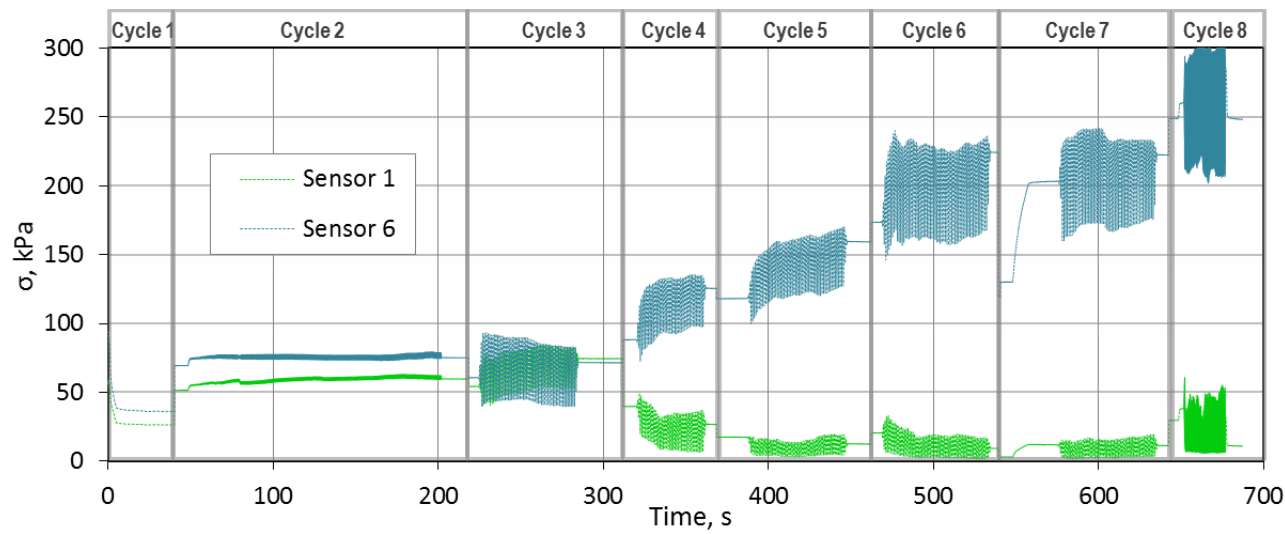

Figure 10. Vertical pressure process in all cycles for the sleeper center and end sensors

During the last cycle No. 8 where the ballast is subjected to the vibration loading of $40 \mathrm{~Hz}$, the dynamic pressure under the sleeper ends growth up to $50 \mathrm{kPa}$. After the unloading, however, the residual pressure under the sleeper ends has no increment. That means, the vibration loading causes the significant homogenization of the dynamic pressure distribution but also causes a somewhat more inhomogeneous residual stress distribution.

Evidentially, there is some relation between the dynamic stress in ballast and the residual stresses, which is also influenced with the position under the sleeper. The following simple explanation is explained with the Figure 11.

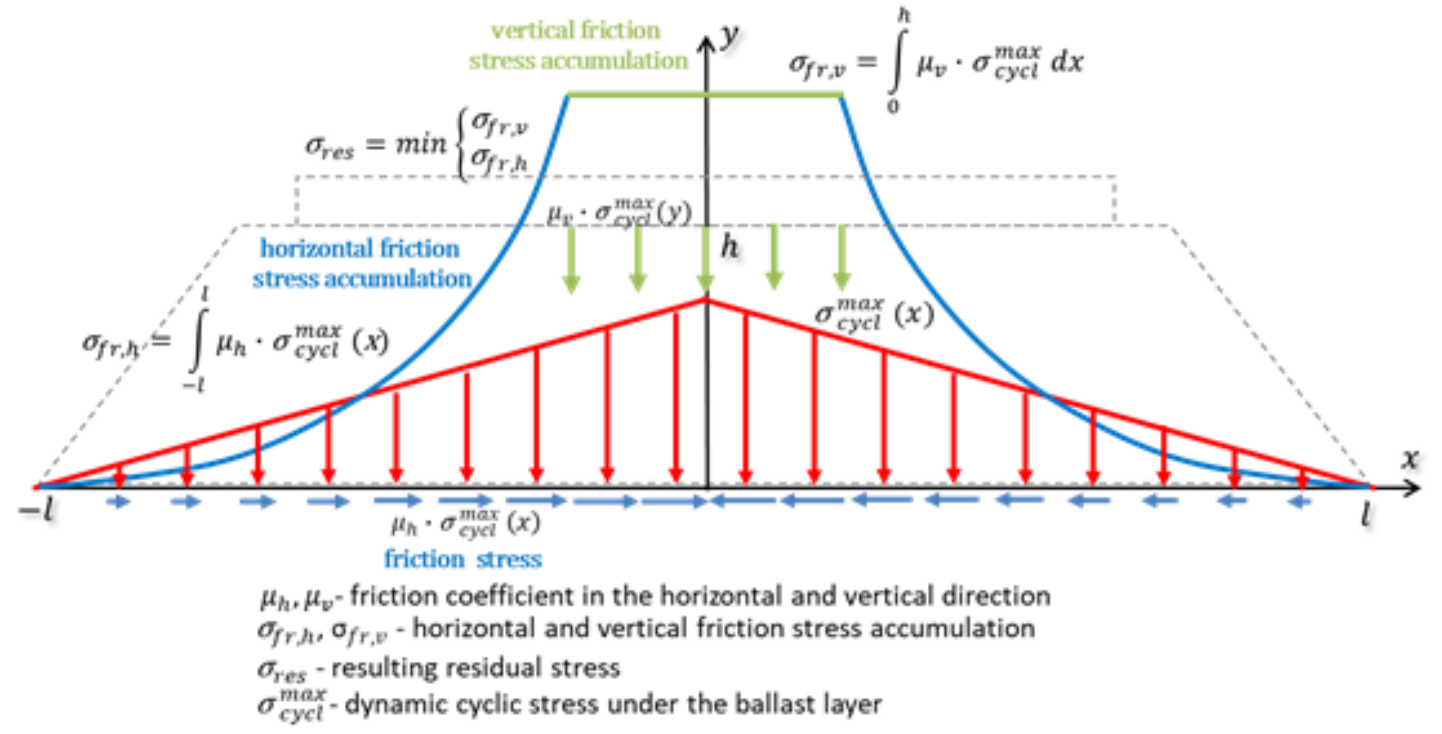

Figure 11. Schematic explanation of the relation between the residual and dynamic stresses

The sleeper loading causes the vertical cyclic pressure in the ballast that activates the horizontal and vertical friction reactions stresses on the walls as well as on the bottom surface. The vertical cyclic pressure in the ballast is measured with the pressure sensors under the ballast and its longitudinal distribution is presented in Figure 8. The distribution is incremental from the both ends of the sleeper to its center and the process can be assumed as linear, that is depicted in Figure 11 as red lines. The activated horizontal friction reactions stresses are accumulated to the residual pressure during the cyclic loading due to interlocking effect. This accumulation process as parabolic lines (see Figure 11) on both sides of the sleeper can be clearly observed in Figure 9 of the experimental measurements. However, the experimental measurements show a different shape from the parabolic process of residual stress distribution under the middle part of the sleeper. In this zone (i.e. middle part) the distribution is almost flat. The fact can be explained with the accumulation of the activated vertical friction reactions over the walls height. Though, the cyclic pressure in the ballast is not measured over the ballast height and under the sleeper but it can be assumed to be more homogenous or flat than measured one 
along the ballast bed. Therefore, the residual stresses under the sleeper middle part (the flat distribution) are limited by the friction in the vertical direction. The residual stresses on the both sides of the sleeper are limited by the parabolic like stress accumulation in the horizontal direction.

\section{Conclusions}

The present research introduced and summarized the experimental measurements of pressure distribution under the ballast layer executed by scaled laboratory tests. The measurements have shown high residual stresses that appear due to the effect of ballast particles interlocking. The effect is related to ballast particles' shapes (crushed grains with angular form) and the interaction of ballast material with bounding elastic medium. (It should be mentioned that the test results will be more different compared to the shown and summarized ones; in case of rounded particles the interlocking effect is much lower between those grains than crushed ones. It can be a future research to compare them.) The simple explanation of the residual stress mechanism is proposed. The residual stresses distribution can be derived from the cyclic dynamical pressures.

The property of ballast layer to accumulate high residual stresses under the incremental dynamic loading is potentially useful as additional means for the increase its resistance to the long-term deformations and therefore for prolonging the track geometry lifecycle (i.e. increase the tamping interval) that resulted in save money. At the same time the effect of residual stresses could have the negative influence on the particle breakage, as well. High residual stress can cause on one side abrasion, and on the other side fragmentation of the grains, that is increased by the dynamic effect of the railway vehicles. Therefore, the future research of the residual stress control as well as its influences is promising for practical applications like ballast reinforcement, geogrids, etc. The authors plan to compare the results of multi-level shear box tests and the present introduced 'movable wall tests', with and without the consideration of geosynthetic inclusions.

\section{References}

Beben, D. (2017). The role of backfill quality on corrugated steel plate culvert behaviour. Baltic Journal of Road and Bridge Engineering, 12(1), 1-11, DOI: https://doi.org/10.3846/bjrbe.2017.01.

Berghold, A. (2016). Wirkungsweise von unterschiedlichen Gleisschotterarten mit und ohne Schwellenbesohlung. ZEVrail, 01 (02), 45-52.

Cai, X., Zhong, Y., Hao, X., Zhang, Y. \& Cui, R. (2019). Dynamic behavior of a polyurethane foam solidified ballasted track in a heavy haul railway tunnel. Advances in Structural Engineering, 22(3), 751-764, DOI: https://doi.org/10.1177/1369433218799154.

Esveld, C. (2001). Modern railway track. (2nd ed.). Zaltbommel: MRT-productions.

Fellin, W. (2002). Hypoplastizität für leicht Fortgeschrittene. Bautechnik, 79 (12), 830-841.

Fendrich, L., Fengler, W. (2013). Handbuch Eisenbahninfrastruktur. Berlin: Springer-Verlag Berlin Heidelberg, DOI: https://doi.org/10.1007/978-3-642-30021-9.

Fischer, S. (2012). Investigation of railway track geometry stabilisation effects of geogrid layers under ballast bed. PhD Thesis, Szechenyi Istvan University Doctoral School of Multidisciplinary Engineering Sciences, 148 p. DOI: https://doi.org/10.13140/RG.2.1.4958.9921. (in Hungarian)

Fischer, S. (2015). Investigation of inner shear resistance of geogrids built under granular protection layers and railway ballast. Nauka ta Progres Transportu, 59 (5), 97-106, DOI: https://doi.org/10.15802/stp2015/53169.

Fischer, S. (2017). Breakage Test of Railway Ballast Materials with New Laboratory Method. Periodica Polytechnica Civil Engineering, 61 (4), 794-802, DOI: https://doi.org.10.3311/PPci.8549.

Fischer, S., Horvát, F. (2011). Investigation of the reinforcement and stabilization effect of geogrid layers under railway ballast. Slovak Journal of Civil Engineering, 19 (3), 22-30.

Gerber, U., Fengler, W. (2009). Oberbau-Effektivität im Spannungsfeld von Investition und Instandhaltung. EIK - Eisenbahn Ingenieur Kompendium, 1, 1-12.

Gerber, U., Fengler, W. (2010). Setzungsverhalten des Schotters. Eisenbahntechnische Rundschau, 4, 170175. 
Göbel, C., Fischer, R. \& Lieberenz, K. (2013). Handbuch Erdbauwerke der Bahnen Planung, Bemessung, Ausführung,Instandhaltung. Hamburg: Eurailpress in DVV Media Group.

Gudehus, G. (2003). Ratcheting und DIN 1054. Mitteilungen des Instituts und der Versuchsanstalt für Geotechnik, Technische Universität Darmstadt, 64, 159-172.

Herle, I. (1997). Hypoplastizität und Granulometrie einfacher Korngerüste. PhD Thesis, Institut für Bodenmechanik und Felsmechanik der Universität Fridericiana in Karlsruhe, No. 142.

Izvolt, L., Harusinec, J. \& Smalo, M. (2018). Optimisation of transition areas between ballastless track and ballasted track in the area of the tunnel turecky vrch. COMMUNICATIONS Scientific Letters of the University of Zilina, 20 (3). 67-76.

Ižvolt, L., Ižvoltová, J. \& Šestáková, J. (2014). Influence of construction of railway superstructure on railway quality. Applied Mechanics and Materials, 617, 54-59.

Izvolt, L., Kardos, J. (2011). Influence of parameters of railway track construction on vertical dynamic interaction vehicle/track. Komunikacie 13 (3), 63-70.

Izvolt, L., Sestakova, J. \& Smalo, M. (2016). Analysis of results of monitoring and prediction of quality development of ballasted and ballastless track superstructure and its transition areas. COMMUNICATIONS Scientific Letters of the University of Zilina, 18 (4), 19-29.

Juhász, E., Fischer, S. (2019). Investigation of railroad ballast particle breakage. POLLACK PERIODICA An International Journal for Engineering and Information Sciences, 14 (2), 1-8, DOI: https://doi.org/10.1556/606.2019.14.1.1.

Klotzinger, E. (2008). Der Oberbauschotter Teil 1: Anforderungen und Beanspruchung. ETR Eisenbahntechnische Rundschau, 1, 34-41.

Kolos, A., Konon, A. \& Chistyakov, P. (2017). Change of ballast strength properties during particles abrasive wear. Procedia Engineering, 189, 908-915, DOI: https://doi.org/10.1016/j.proeng.2017.05.141.

Kovalchuk, V., Kovalchuk, Y., Sysyn, M., Stankevych, V. \& Petrenko, O. (2018). Estimation of carrying capacity of metallic corrugated structures of the type Multiplate MP 150 during interaction with backfill soil. Eastern-European Journal of Enterprise Technologies, 1 (1-91), 18-26, DOI: https://doi.org/10.15587/17294061.2018.123002.

Lang, R., Yang, A. \& Yan, S. (2019). Analysis of Stress-strain Characteristics of Geogrid Reinforced Crushed Gravel. KSCE Journal of Civil Engineering, 23 (2), 549-555, DOI: https://doi.org/10.1007/s12205-018-09434.

Li, D., Hyslip, J., Sussmann, T. \& Chrismer, S. (2015). Substructure. In Li, D., Hyslip, J., Sussmann, T. \& Chrismer, S. Railway Geotechnics (pp. 90-95). London: CRC Press. DOI: https://doi.org.10.1201/b18982-4.

Lichtberger, B. (2005). Track compendium. Hamburg: Eurailpress.

Liu, Q., Lei, X., Rose, J.G. \& Purcell, M. L. (2017). Pressure measurements at the tie-ballast interface in railroad tracks using granular material pressure cells. Joint Rail Conference, JRC 2017, 1-9, DOI: https://doi.org/10.1115/JRC2017-2219.

Liu, S., Huang, H. \& Qiu, T. (2018). Evaluating ballast stabilization during initial compaction phase. ASTM Special Technical Publication, STP 1605, 105-122, DOI: https://doi.org/10.1520/STP160520170032.

Meißner, S. (2014). Numerische Studien zum in-situ Setzungsverhalten von Gründungssystemen unter zyklischer Einwirkung in nichtbindigen Böden, Mitteilungen des Instituts für Werkstoffe und Mechanik im Bauwesen der Technischen Universität Darmstadt, 42, 33-62.

Nabochenko, O., Sysyn, M., Kovalchuk, V., Kovalchuk, Yu., Pentsak, A., \& Braichenko, S. (2019). Study railroad track geometry deterioration as a result of an uneven subsidence of the ballast layer. Eastern-European Journal of Enterprise Technologies, 50-59, DOI: https://doi.org/10.15587/1729-4061.2019.154864.

Plášek, O., Hruzíková, M. (2017). Under sleeper pads in switches \& crossings. IOP Conference Series: Materials Science and Engineering, 236 (1), 12-45, DOI: https://doi.org/10.1088/1757-899X/236/1/012045. 
Ramūnas, V., Vaitkus, A., Laurinavičius, A., Čygas, D. \& Šiukščius, A. (2017). Prediction of lifespan of railway ballast aggregate according to mechanical properties of it. Baltic Journal of Road and Bridge Engineering, 12 (3), 203-209, DOI: https://doi.org/10.3846/bjrbe.2017.25.

Selig, E. T., Waters, J. M. (1994). Track Geotechnology and Substructure Management. London: Thomas Telford.

Suhr, B., Marschnig, S. \& Six, K. (2018). Comparison of two different types of railway ballast in compression and direct shear tests: experimental results and DEM model validation. Granular Matter, 20 (4), 70(1-13), DOI: https://doi.org/10.1007/s10035-018-0843-9.

Sysyn, M., Gerber, U., Kovalchuk, V. \& Nabochenko, O. (2018). The complex phenomenological model for prediction of inhomogeneous deformations of railway ballast layer after tamping works. Archives of Transport, 46 (3), 91-107, DOI: https://doi.org/10.5604/01.3001.0012.6512.

Sysyn, M., Nabochenko, O., Gerber, U. \& Kovalchuk, V. (2019). Evaluation of railway ballast layer consolidation after maintenance works. Acta Polytechnica, 58 (6), 1-16.

Veit, P. (2013). Instandhaltung und Anlagenmanagement des Fahrweges. Maintenance and asset management of permanent way. In: Fendrich, L., Fengler, W., (Eds.), Handbuch Eisenbahninfrastruktur. Field manual Railway Infrastructure (pp. 1009-1054). Berlin: Springer-Verlag Berlin Heidelberg.

Wang, B., Martin, U. \& Rapp, S. (2016). Vibration Characteristic Analysis of Ballast with Different Aspect Ratios by Means of the Discrete Element Method. Geotechnical Special Publication, 2016-January (268 GSP), 16-23, DOI: https://doi.org/10.1061/9780784480113.003.

Wang, B., Martin, U. \& Rapp, S. (2017). Discrete element modeling of the single-particle crushing test for ballast stones. Computers and Geotechnics, 88, 61-73, DOI: https://doi.org/10.1016/j.compgeo.2017.03.007.

Wang, B., Martin, U. (2018). A random form generator for ballast stones. Proceedings of the Institution of Mechanical Engineers, Part F: Journal of Rail and Rapid Transit, 232 (6), 1660-1670, DOI: https://doi.org/10.1177/0954409717743604.

Watts, T. J., Rose, J. G. \& Russell, E. J. (2018). Relationships between wheel/rail surface impact loadings and correspondingly transmitted tie/ballast impact pressures for revenue train operations". Joint Rail Conference, JRC 2018, V001T01A014 (1-10), DOI: https://doi.org/10.1115/JRC2018-6184. 